\title{
MAKALAH
}

KEWIRAUSAHAAN

PASAR DAN PEMASARAN

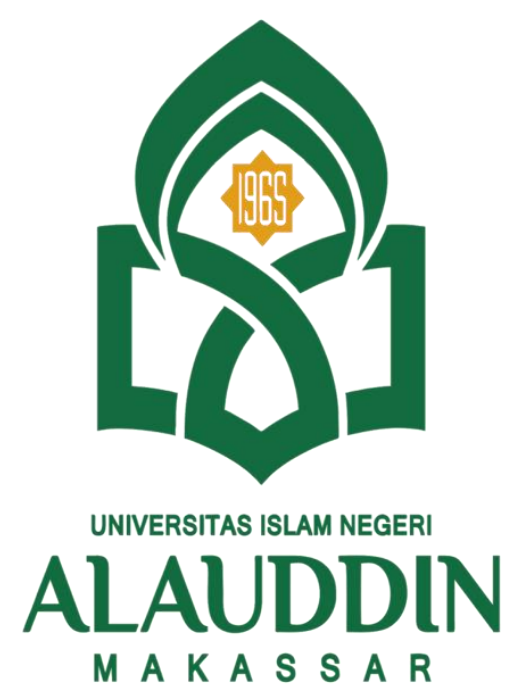

Disusun Oleh:

FEBIANIL (90500120057)

PRODI PERBANKAN SYARIAH

FAKULTAS EKONOMI DAN BISNIS ISLAM

UNIVERSITAS ISLAM NEGERI (UIN) ALAUDDIN MAKASSAR

2021 


\section{KATA PENGATAR}

Puji syukur kita panjatkan kepada Tuhan Yang Maha Esa atas keehadirat-Nya yang telah melimpahkan rahmat,dan hidayah-Nya kepada kita semua. Hingga kami dapat menyelesaikan tugas mata kuliah Kewirausahaan yaitu tugas terstruktur pembuatan makalah tentang "Pasar dan Pemasaran*

Kami mengucapkan terimakasih kepada Dosen Pembimbing yang telah membimbing kami dalam proses pemahaman mata kuliah ini.

Kami menyadari bahwa masih banyak kekeliruan kami dalam menyusun makalah ini kurang lebihnya, pribadi kami mohon maaf sebesar-besarnya, karena kesempurnaan hanya milik Allah Swt dan kekurangan hanya milik kita bersama. 


\section{DAFTAR ISI}

KATA PENGATAR

DAFTAR ISI

BAB 1 PENDAHULUAN
A. Latar Belakang
B. Rumusan Masalah
C. Tujuan Penulisan

\section{BAB 2 PEMBAHASAN}
A. Pengertian Pasar dan Pemasaran
B. Tujuan dan manfaat pemasaran
C. Strategi pemasaran
D. Strategi Bauran pemasaran

\section{BAB 3 PENUTUP}
A. Kesimpulan
B. Saran

\section{DAFTAR PUSTAKA}

\section{BAB 1 \\ PENDAHULUAN}

\section{A. Latar Belakang}

Dalam suatu pasar terdapat berbagai macam pembeli dengan Kebutuhan dan perilaku yang berbeda-beda. Oleh karena itu, sangat sulit bagi Suatu produk untuk menguasai pasar secara keseluruhan. Strategi 
yang umum Ditempuh adalah memilih segmen pasar tertentu yang dapat memberikanKedudukan yang paling kuat bagi produk bersangkutan. Strategi ini yang Disebut dengan market positioning.

Menarik konsumenmelakukan pembelian, maka perusahaan harus bisa menerapkan suatu strategi pemasaran yang tepat sesuai dengan kondisi pasar yang dihadapi. Keberhasilanstrategi pemasaran dipengaruhi oleh beberapa faktor yaitu riset dan analisis pasar,keputusan tentang produk, penetapan harga, promosi, dan distribusi. Agar produkyang dipasarkan dapat berhasil, maka perusahaan harus menggunakan konsep pemasaran yang meliputi manfaat, mutu atau kualitas dan kepuasan antarakebutuhan dengan keinginan.

\section{B. Rumusan Masalah}

Rumusan masalah dalam makalah ini yaitu:

1. Apakah pengertian pasar dan pemasaran?

2. Bagaimana tujuan dan fungsi pemasaran ?

3. Bagaimana Strategi pemasaran?

4. Bagaimana strategi Bauran pemasaran?

\section{Tujuan}

1. Untuk mengetahui definisi dari pasar dan pemasaran.

2. Untuk mengetahui tujuan dan fungsi pemasaran.

3. Untuk mengetahui strategi pemasaran.

4. Untuk mengetahui strategi bauran pemasaran. 


\section{BAB 2}

\section{PEMBAHASAN}

\section{A. Pengertian Pasar dan Pemasaran}

Menurut Dr. Suliyanto pasar adalah jumlah seluruh permintaan barang Atau jasa oleh pembeli-pembeli pontensial, sedangkan menurut stanton pasar Didefenisikannya sebagai orang-orang yang mempunyai keinginan untuk Puas, uang untuk berbelanja, dan kemauannya untuk membelanjakannya ${ }^{1}$.

Dan pasar menurut penulis adalah tempat penawaran atau permintaan pelaku Pasar untuk memperoleh atau menawarkan barang atau jasa sesuai dengan Keinginannya dengan cara berbelanja atau menjual menggunakan alat tukar Untuk tujuan memenuhi kebutuhan hidupnya baik kebutuhan primer,Sekunder, maupun tersier. 
Pemasaran menurut perspektif syariah adalah segala aktivitas yang Dijalankan dalam kegiatan bisnis berbentuk kegiatan penciptaan nilai yang Memungkinkan siapapun yang melakukannya bertumbuh serta Mendayagunakan kemanfaatannya yang dilandasi atas kejujuran, keadilan, Keterbukaan, dan keikhlasan sesuai dengan proses yang berprinsip pada akad Bermuamalah islami atau perjanjian transaksi bisnis dalam Islam ${ }^{2}$.

Pemasaran merupakan hal yang penting bagi perusahaan untuk Memaksimalkan strategi penjualan dan untuk memperoleh keuntungan Demi kelangsungan hidup suatu perusahaan. Menurut American Marketing Assosiation dalam Sudaryono ( 2016 :41) "Pemasaran adalah fungsi dari Organisasi dan serangkaian suatu proses penciptaan, mengkomunikasikan, Dan menyampaikan nilai bagi para konsumen serta mengelola hubungan Antara konsumen dengan perusahaan untuk memberikan manfaat bagi Konsumen dan produsen.Menurut Kotler (dalam Sudaryono, 2016 :41) pemasaran adalah Suatu proses sosial dan manajerial dimana suatu individu ataupun Kelompok mendapatkan apa yang mereka inginkan serta butuhkan dengan Penciptaan dan pertukaran suatu produk. Menurut Brech (dalam Sudaryono, 2016:39) Pemasaran adalah Proses menentukan permintaan konsumen atas sebuah produk atau jasa, Memotivasi penjualan produk atau jasa tersebut.

Pemasaran dalam fiqih Islam dikenal dengan wakalah (perwakilan). Wakalah dapat diartikan sebagai penyerahan, pendelegasian, atau pemberian Kepercayaan atau mandat. Wakalah juga dapat diartikan sebagai penyerahan Sesuatu kegiatan atau aktivitas dari seseorang atas dasar kepercayaan kepadaOrang lain untuk melakukan hal yang diamanatkan. ${ }^{3}$

Berdasarkan pengertian pemasaran di atas, maka terdapat perbedaan Yang mencolok antara pemasaran menurut perspektif Islam dan konvensional. Perbedaan tersebut terletak pada kejujuran, keadilan, keterbukaan, dan Keikhlasan yang tertanam dalam pemasaran perspektif Islam. 
Jadi, pasar merupakan tempat untuk memasarkan barang dan jasa baik Berupa penawaran maupun permintaan, sedangkan pemasaran adalah strategi Dalam memasarkan barang dan jasa yang akan ditawarkan.

Pemasaran dalam versi syariah dapat didefenisikan sebagai sebuah Disiplin strategis yang mengarahkan proses penciptaan, penawaran, dan Perubahan values dari satu inisiator kepada stakeholder-nya, yang dalam Keseluruhan prosesnya tidak bertentangan dengan akad dan prinsipprinsip Muamalah dalam Islam, maka dapat disimpulkan bahwa pemasaran sama Dengan perwakilan (wakalah) dalam fiqih Islam. Dengan demikian, secara syar'i dalil-dalil tentang pemasaran dengan Seluruh lingkup atau elemen-elemen pemasaran yang ada di dalamnya dapat Kita temukan dalam dalil-dalil syar'i tentang wakalah. ${ }^{5}$

\section{B. Tujuan dan Fungsi Pemasaran}

a. Tujuan pemasaran

Menurut Granroos (dalam Sudaryono, 2016) tujuan dari pemasaran adalah untuk Menjalin, mengembangkan, dan menkonsentrasikan hubungan dengan pelanggan untuk jangka panjang dan sedemikian rupa sehingga dapat terpenuhinya tujuan dari masing-masing pihak. Hal ini biasanya dilakukan dengan proses pertukaran dan saling memenuhi.

b. Manfaat pemasaran

Fungsi Pemasaran menurut (Sudaryono 2016 :50) adalah sebagai berikut:

- Fungsi pertukaran

Dengan fungsi pertukaran, pembeli dapat membeli produk yang Mereka inginkan dari produsen, dengan menukarkan uang dengan Suatu produk maupun menukar produk dengan produk (barter) dan Pembeli bisa memakai produk sendiri atau untuk dijual kembali. Pertukaran merupakan salah satu cara mendapatkan suatu produk. 
- Fungsi distribusi fisik

Distribusi fisik suatu produk dapat dilakukan dengan cara Menyimpan produk, mengangkut produk dari produsen ke konsumen Yang membutuhkan dengan cara mengangkut melalui darat, air maupun Udara. Tujuan penyimpanan produk adalah agar produk tersebut terjaga Kualitasnya dan menjaga pasokan agar tidak kekurangan saat Dibutuhkan.

- Fungsi perantara

Untuk menyampaikan produk dari tangan produsen ke tangan Konsumen dapat dilakukan melalui perantara pemasaran yang Menghubungakn aktivitas pertukaran dengan distribusi fisik. Aktivitas Fungsi perantara antara lain pengurangan risiko, pembiayaan, pencarain Informasi serta standarisasi dan klasifikasi produk.

\section{C.Strategi pemasaran}

Strategi pemasaran adalah serangkaian tujuan dan sasaran, kebijakan Serta aturan yang memberikan arah kepada usaha-usaha pemasaran dari waktu ke waktu pada masing-masing tingkatan serta lokasinya. Strategi pemasaran secara umum terdiri dari tiga tahapan, yaitu segmentasi pasar (segmenting) penetapan pasar sasaran (targeting), dan penetapan posisi pasar (positioning).

1. Segmentasi pasar (segmenting) merupakan kegiatan membagi-bagi pasar Yang bersifat heterogen dari suatu produk ke dalam satuansatuan pasar Yang besifat homogen. Segmentasi pasar bertujuan agar perusahaan lebih Mudah dalam melayani berbagai kebutuhan dan keinginan pasar. Segmentasi pasar dapat dilakukan dengan beberapa cara berikut ini:

- Segmentasi geografis

- Segmentasi demografis

- Segmentasi psikografis

2. Penetapan pasar sasaran (targeting) adalah pemilahan pasar sasaran dari Kumpulan pembeli dengan kebutuhan atau karakteristik serupa yang akanDilayani perusahaan. Dalam pemilihan target pasar perlu Mempertimbangkan hal-hal berikut : 
- Sumber daya perusahaan

- Variabilitas produk

- Tahapan produk dalam daur hidup

- Variabilitas pasar

- Stategi pesaing

3. Penetapan posisi pasar (positioning) adalah tindakan merancang Penawaran dan citra perusahaan sehingga menempati suatu posisi Kompetitif yang berarti dan berada dalam benak pelanggan sasarannya. Sehingga perusahaan perlu menentukan posisi pasar agar produknya bisa dikenali oleh para konsumen.

\section{Bauran (Marketing Mix)}

Bauran pemasaran merupakan kombinasi dari empat variabel yang merupakan inti dari sistem pemasaran yang dapat dikendalikan oleh perusahaan. Variabel tersebut adalah produk (product), harga (harga), promosi (promotion), dan tempat/lokasi (place)

Penjelasan variabel-variabel bauran pemasaran tersebut sebagai berikut.

1. Produk (Product)

Produk adalah suatu yang bisa ditawarkan di pasar untuk Mendapatkan perhatian, pembelian, pemakaian, atau konsumsi yan Dapat memenuhi keinginan atau kebutuhan. Produk dapat berupa barang Ataupun jasa yang ditawarkan oleh pelaku pasar.

2. Harga (Price)

Harga adalah sejumlah uang dan atau barang yang dibutuhkan Untuk mendapatkan kombinasi dari barang lain yang disertai dengan Pencarian jasa. Penentuan tingkat harga sangat menentukan keberhasilan Sebuah bisnis. Oleh karena itu, dalam menentukan harga suatu produk

Harus sangat diperhatikan sekali oleh perusahaan yang menjalankan Bisnisnya.

3. Promosi (Promotion)

Promosi merupakan hal yang sangat penting dalam memasarkannProduk yang diciptakan. Tanpa promosi, berkemungkinan besar para

tidak akan mengenal produk yang tawarkan. Promosi merupakan Kegiatan untuk memperkenalkan produk sekaligus mempublikasikan Produk yang diciptakan. Promosi dalam 
ekonomi syariah harus memperhatikan nilai-nilai Kejujuran dan menjauhi penipuan.Media atau sarana dan metode yang Digunakan harus sesuai dengan syariah. ${ }^{12}$

4. Tempat/Lokasi (Place)

Tempat/lokasi bank merupakan tempat dimana Diperjualbelikannnya produk cabang bank dan pusat pengendalian Perbankan. Dalam praktiknya ada beberapa macam lokasi kantor bank, Yaitu lokasi kantor pusat, cabang utama, cabang pembantu, kantor kas, Dan lokasi mesin-mesin Anjungan Tunai Mandiri.

Pemasaran dalam islam harus mengedepankan prinsip syariah agar pemasaran yg dilakukan tidak menjerumuskan orang lain. Pemasaran dalam islam memiliki beberapa karakteristik yaitu rabbaniyyah, akhlakiyyah, ini'iyyah dan insaniyyah.

\section{PENUTUP}

\section{A. Kesimpulan}

Pemasaran merupakan hal yang penting bagi perusahaan untuk Memaksimalkan strategi penjualan dan untuk memperoleh keuntungan Demi kelangsungan hidup suatu perusahaan. Pasar merupakan tempat untuk memasarkan barang dan jasa baik Berupa penawaran maupun permintaan, sedangkan pemasaran adalah strategi Dalam memasarkan barang dan jasa yang akan ditawarkan.

Strategi pemasaran adalah serangkaian tujuan dan sasaran, kebijakan Serta aturan yang memberikan arah kepada usaha-usaha pemasaran dari waktu ke waktu pada masing-masing tingkatan serta lokasinya.

\section{B. Saran}

Pasar dan pemasaran merupakan hal yang sangat penting dalam suatu perusahaan. Strategi pasar dan pemasaran yang baik akan menentukan kemajuan suatu perusahaan. Maka sebaiknya dengan adanya 
Strategi pasar dan pemasaran yang tersedia saat ini bisa digunakan secara baik sehingga dapat meningkatkan kualitas perusahaan. Serta fisi dan misi pasar dan pemasaran harus sejalan dengan fisi dan misi perusahaan bisa melakukan pengadaan karyawan secara tepat.

\section{DAFTAR PUSTAKA}

Abdullah, Amrin, Strategi Pemasaran Asuransi Syariah, (Jakarta :

Grasindo, 2007), h.1.

Muhammad Syakir Sula, Asuransi Syariah, (Jakarta: Gema Insani, 2004), h. 424-245.

Hermawan Kartajaya dan Muhammad Syakir Sula, Syariah Marketing, (Bandung: Mizan, 2006), Cet. Ke- I, h. 22. 